\title{
Reform and Practice of SCM Curriculum Based on Project Teaching Method
}

\author{
Zheng Huang \\ Electrical Engineering College \\ Guizhou Institute of Technology \\ Guiyang 55003, China
}

\author{
Fang Wen \\ Electrical Engineering College \\ Guizhou Institute of Technology \\ Guiyang 55003, China
}

\begin{abstract}
Principle and Application of SCM (Single Chip Microcomputer) is a very practical course. The traditional teaching is not adapted to the training objectives of engineering education in Universities under the new situation. This paper introduces a kind of project teaching method with the combination of project teaching content and project teaching implementation plan. This method has achieved good teaching effects in practice teaching, which stimulates the students' learning interest, strengthens the practical teaching of SCM, cultivates students' ability of practice and innovative thinking, and has achieved good teaching effect in practice teaching.
\end{abstract}

Keywords-Single chip microcomputer course ; Teaching Reform ; Curriculum

\section{INTRODUCTION}

"Single chip microcomputer principle and application" course is an important major course for the engineering specialty, and it is also a very practical course. It not only demands students to master some basic theoretical knowledge, more important is to have strong ability of practical application and strong ability of self-study and innovation spirit, the development trend of keep up with technology, to achieve the sustainable development

With the rapid development of science and technology and the deepening of education and teaching reform, the traditional SCM course teaching exist some much-needed reform and construction, mainly in the following aspects:

\section{A. The contents of each chapter are isolated.}

The contents of this course are heavy and difficult, a lot of content independent blocks, Like pearls scattered hard to hold. Most of the students can often pick up on a few pearls and not a bunch of beautiful bead chain at the end of the course. That cannot achieve the ideal teaching effect.

\section{B. The pertinence of experiment teaching content is not} strong. It lacks of the link between theory and practice

Although the current training program to increase the proportion of design and comprehensive experiments, but many of the design experiment is in fact just let the students connect the lines, this lack of real engineering practice experiment opportunities, could not achieve the purpose of improving the students ' practical ability.

\section{Students lack the concept of the project, and Lack of understanding of the process of the whole project.}

The training objective of our school is to cultivate the applied advanced Technical personnel. If the students do not understand what part of a project to complete and how to evaluate a project before they took to the society, we do not achieve the educational goals. Traditional teaching methods will inevitably lead students to do experiments only to complete the experimental task. It does not to establish the concept of the project, not to master the project design methods and how to evaluate the project.

In view of the above problems, it is necessary to reform the theory and practice teaching of SCM Course.

\section{Project Teaching Method}

"Project-based teaching" is a teaching activity which is carried out through the implementation of a complete project. Its purpose is combining the theory and practice organically in the classroom teaching. It fully explores the students' creative potential and improves students' comprehensive ability to solve practical problems. The key of the project teaching is to design and develop a project task according to the teaching task and the goal.

Its teaching content is based on the real work process or actual working process simulation platform as the carrier. Through the students' hands-on operation, it deepens students' understanding of knowledge. As a guide of the learning process, teachers only make directional guidance for students.SCM project teaching break based on knowledge system of curriculum structure, with a specific project to derive the knowledge of SCM, and guide students to learn. It inspires students to use the knowledge and skills to solve a problem, and finally implement the project. This teaching mode makes the students learn from "listening to learning" into "learning by doing" to stimulate students' learning interest and enthusiasm effectively. It allows students to come into contact with the practical problems encountered in the work, more able to develop students' practical ability, analytical skills, collaboration and other important capabilities.

\section{THE IMPLEMENTATION SCHEME OF SCM PROJECT TEACHING}

In view of the problems existing in the teaching of single chip microcomputer, we put forward the scheme of project 
teaching reform, the implementation of the teaching can be divided into the optimization project, the development plan, the implementation plan, the results check and evaluation, etc.. The specific subdivision steps are shown in fig. 1.

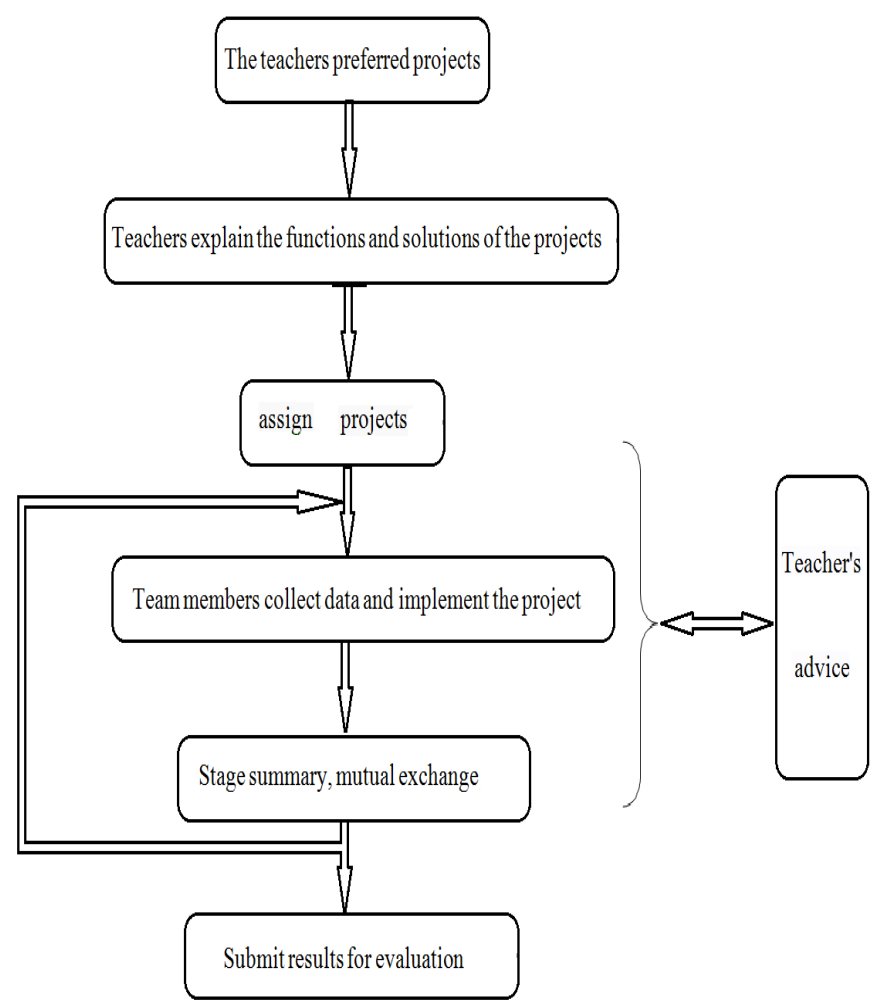

\section{A. Selected items}

This link is the key to the success of the project teaching method. The designers use their knowledge and mastery of the teaching course to determine an appropriate project and identify tasks, paths, and effects in the project. At the same time, the possible problems is expected

Therefore, this link depends not only on the teachers' personal mastery, but also depends on a team to grasp.

For our SCM courses, a total of seven projects designed as shown in Table 1. They include understanding single chip microcomputer, SCM input / output applications, Timer / counter and interrupt system applications, Application of digital tube and keyboard, Serial communication applications, $\mathrm{A} / \mathrm{D}$ and $\mathrm{D} / \mathrm{A}$ converter interface, Design of single chip microcomputer application system. We select some of the more comprehensive design tasks for SCM application system design. They are design of constant temperature control system, design of digital electronic clock, design of DC motor control system, and design of automobile control system.

These items cover all of the hardware resources and expansion methods. And software learning is throughout each project. Through the implementation of these projects, students have a very good practice for SCM hardware and software applications. This improves students' comprehensive application ability and lays a solid foundation for the students.

Fig. 1. Schematic diagram of project teaching method

TABLE I. SCM COURSE PRACTICE PROJECT

\begin{tabular}{|c|c|}
\hline Project name & Specific content \\
\hline Project 1: understanding SCM & $\begin{array}{l}\text { 1. A variety of single-chip package } \\
\text { 2. SCM minimum system } \\
\text { 3.SCM experimental device, development software C Keil and the use of } \\
\text { Proteus software }\end{array}$ \\
\hline Project 2: SCM input / output applications & $\begin{array}{l}\text { 1. Design of Two Traffic Signal } \\
\text { 2. Analog sound and light control lamp design } \\
\text { 3. Buzzer sound alarm }\end{array}$ \\
\hline Project 3: Timer / counter and interrupt system applications & $\begin{array}{l}\text { 1. Design of Digital Stopwatch } \\
\text { 2. Pulse count measurement } \\
\text { 3. Speed counter } \\
\text { 4. Interrupt priority design } \\
\end{array}$ \\
\hline Project 4: Application of digital tube and keyboard & $\begin{array}{l}\text { 1. Display Design of Eight - segment Digital } \\
\text { 2. Keyboard identification and digital tube display design } \\
\text { 3. Electronic code lock design }\end{array}$ \\
\hline $\begin{array}{l}\text { Project 5: } \\
\text { Serial communication applications, }\end{array}$ & $\begin{array}{l}\text { 1. Design of dual computer communication of SCM } \\
\text { 2. Communication Design between SCM and PC }\end{array}$ \\
\hline Project 6: $\mathrm{A} / \mathrm{D}$ and $\mathrm{D} / \mathrm{A}$ converter interface & $\begin{array}{l}\text { 1. Design of Digital Voltmeter System } \\
\text { 2. Circuit Design of Sawtooth Wave Generator }\end{array}$ \\
\hline $\begin{array}{l}\text { Project 7: Design of single chip microcomputer application } \\
\text { system. }\end{array}$ & $\begin{array}{l}\text { 1. Design of the constant temperature control system } \\
\text { 2. Design of digital electronic clock } \\
\text { 3. Design of DC motor control system, } \\
\text { 4. Design of automobile control system }\end{array}$ \\
\hline
\end{tabular}

\section{B. Making plans}

Through the teacher's narration, students work out the project work plan, determine the work steps and procedures, and eventually get the teacher's approval. In this process, teachers should guide students in the established direction to think, to develop a practical plan, in essence, which is a process of imparting knowledge. 


\section{Implementation Plan}

Students determine the division of labor in the group and the form of team work, and then work in accordance with established procedures. The plan is realized and the student consolidates the knowledge learned by implementing the plan. Therefore, this is the process of transforming knowledge into ability. Students are the main body, and the teacher can only be the student's assistant in the process.

Each project design consists of nine parts: project name, the purpose of the project, review of theoretical knowledge, the project hardware circuit and simulation, software programming, project notes, Welding circuit board, examples, project development, respectively.

In the course of the project implementation, it is not only to learn the theoretical knowledge, but also to contact the practical application, so that students can understand the use of these hardware resources and application occasions.

\section{Check Assessment}

Students are expected to self-assess their own work results and then be assessed by the teacher. Teachers and students work together to judge the problems in the work of the project, to discuss ways to solve the problem. Find out the reasons for the difference between the results by comparing the evaluation results of the teachers and students.

\section{CONCLUSIONS}

The practice of SCM course is very strong. The projectoriented instructional design guides the students learn to do and provides students with a good practice space. It can attract the interest of students, greatly enhance the enthusiasm and initiative of students to learn, enhance the students' practical ability, and improve the quality of teaching.

\section{ACKNOWLEDGMENT}

This research was financially supported by Guizhou Province "electrical engineering and automation" professional comprehensive reform pilot project (2013), Guizhou province colleges and universities teaching contents and curriculum system reform project (Grant No. 201437802) and the key reform projects of Guizhou institute of technology (Grant No. 20131007).

\section{REFERENCES}

[1] Zhao Yue jing, Chen Ji rong, Zhang Yong di. Teaching reform of innovation and practice of Single Chip Microcontroller's Principle and Application $[\mathrm{J}]$. Experimental Technology and Management. 2013(30):176-179.

[2] Hang Jing jing, Li Yong wei. Research and Exploration on the Project driven Teaching Base on MCU Course[J]. Journal of EEE. 2014(36):8792.

[3] Yao Li- juan. Application of Project Teaching Method in Teaching[J]. Journal of education institute of Taiyuan university.2007(2):80-83.

[4] Yue Hong. Application of Project Teaching Method and Proteus Stimulation in Microcontroller Teaching[J]. Vocational and technical education.2011(32):46-49. 